\title{
Correlation between the chemical structure of biodiesel and its physical properties
}

\author{
*A. A. Refaat \\ Department of Chemical Engineering, Faculty of Engineering, Cairo University, Egypt \\ Received 15 July 2009; $\quad$ revised 10 August 2009; accepted 20 August 2009; $\quad$ available online 1 September 2009
}

\begin{abstract}
Biodiesel is a renewable, biodegradable, environmentally benign, energy efficient, substitution fuel which can fulfill energy security needs without sacrificing engine's operational performance. Thus it provides a feasible solution to the twin crises of fossil fuel depletion and environmental degradation. The properties of the various individual fatty esters that comprise biodiesel determine the overall properties of the biodiesel fuel. In turn, the properties of the various fatty esters are determined by the structural features of the fatty acid and the alcohol moieties that comprise a fatty ester. Better understanding of the structure-physical property relationships in fatty acid esters is of particular importance when choosing vegetable oils that will give the desired biodiesel quality. By having accurate knowledge of the influence of the molecular structure on the properties determined, the composition of the oils and the alcohol used can both be selected to give the optimal performance. In this paper the relationship between the chemical structure and physical properties of vegetable oil esters is reviewed and engineering fatty acid profiles to optimize biodiesel fuel characteristics is highlighted.
\end{abstract}

Keywords: Biodiesel; Cetane number; Oxidative stability; Vegetable oil; Viscosity

\section{INTRODUCTION}

Biodiesel refers to a diesel-equivalent, processed fuel derived from biological sources. This renewable, emissions reducing fuel is considered by many to be the 'green fuel' of choice. It is assumed that the use of "biodiesel" to describe esters of vegetable oils and animal fats was coined about 1984, was in limited use up to 1991, and became generally accepted after that date. After 1991, the use of the word "biodiesel" expanded exponentially (Knothe, 2005a). Who actually used it first is still open for speculation (van Gerpen et al., 2007). Biodiesel is defined by the World Customs Organization (WCO) as "a mixture of mono-alkyl esters of long-chain [C16-18] fatty acids derived from vegetable oils or animal fats, which is a domestic renewable fuel for diesel engines and which meets the specifications of ASTM D 6751. It can also be used as a fuel additive” (WCO, 2007).

Any fatty acid source may be used to prepare biodiesel. Thus, any animal or plant lipid should be a ready substrate for the production of biodiesel. The source for biodiesel production is chosen according to the availability in each region or country. Factors

ه *Corresponding Author Email: aarefaat@hotmail.com Tel./Fax: +20 122277897 such as supply, cost, storage properties and engine performance will determine whether a particular potential feedstock is actually adopted for commercial fuel production. The choice of oil for biodiesel production depends on local availability and corresponding affordability. Thus, rapeseed and sunflower oils are used in the European Union, palm oil predominates in biodiesel production in tropical countries and soybean oil and animal fats is the major feedstock in the United States (Haas and Foglia, 2005).

The use of edible vegetable oils and animal fats for biodiesel production has recently been of great concern because they compete with food materials - the food versus fuel dispute (Srinivasan, 2009). There are concerns that biodiesel feedstock may compete with food supply in the long-term (Lam et al., 2009). Hence, the recent focus is the use of non-edible plant oil source as the feedstock for biodiesel production meeting the international standards. Non-edible crude vegetable oils include Jatropha curcas (Achten et al., 2008; Berchmans and Hirata, 2008; Carvalho et al., 2008), Pongamia pinnata (Karmee et al., 2006; Naik et al., 2008; Scott et al., 2008) and Brassica carinata (Cardone et al., 2002; Dorado et al., 2004; Vicente et al., 2005). 
Quality standards are prerequisites for the commercial use of any fuel product. Since the implementation of the European standard specification EN 14214 in 2004, a standardized definition for biodiesel has been agreed as fatty acid methyl esters (FAME) from any kind of feedstock, including recycled frying oils, under fulfilling the given quality specifications. Thus, biodiesel produced from recycled frying oils has the same possibilities to be utilized. The new process technologies developed during the last years made it possible to produce biodiesel from recycled frying oils comparable in quality to that of virgin vegetable oil biodiesel with an added attractive advantage of being lower in price (Canakci, 2007; Chhetri et al., 2008; Refaat et al., 2008a). From a waste management standpoint, producing biodiesel from used frying oil is environmentally beneficial, since it provides a cleaner way for disposing these products; meanwhile, it can yield valuable cuts in $\mathrm{CO}_{2}$ as well as significant tailpipe pollution gains.

Fatty acids are almost entirely straight chain aliphatic monocarboxylic acids. The broadest definition includes all chain lengths, but most natural fatty acids are $\mathrm{C} 4$ to $\mathrm{C} 22$. Naturally, occurring fatty acids share a common biosynthesis. The chain is built from two carbon units and cis double bonds are inserted by desaturase enzymes at specific positions relative to the carboxyl group. This results in even-chain-length fatty acids with a characteristic pattern of methylene interrupted cis double bonds. A large number of fatty acids, varying in chain length and unsaturation, result from this pathway (Scrimgeour, 2005). Several methods to reduce the high viscosity of vegetable oils to enable their use in common diesel engines without operational problems such as engine deposits have been investigated: blending with petrodiesel, pyrolysis, microemulsification (cosolvent blending) and transesterification (Ma and Hanna, 1999). Among these the transesterification reaction is the only which leads to the product commonly known as biodiesel, i.e., alkyl esters of oils and fats (van Gerpen and Knothe, 2005).

Transesterification is the general term used to describe the important class of organic reactions where an ester is transformed into another through interchange of the alkoxy moiety (Freedman et al., 1986). Transesterification involves stripping the glycerin from the fatty acids with a catalyst such as sodium or potassium hydroxide and replacing it with an anhydrous alcohol, usually methanol. The resulting raw product is then centrifuged and washed with water to cleanse it of impurities. This yields methyl or ethyl ester (biodiesel), as well as a smaller amount of glycerol, a valuable by-product used in making soaps, cosmetics, and numerous other products. The three basic methods of ester production from oils/fats are the base-catalyzed transesterification, the acidcatalyzed esterification, and enzymatic catalysis. The most commonly used method of which is the basecatalyzed transesterification technique as it is the most economical process (Singh et al, 2006).

The properties of the various individual fatty esters that comprise biodiesel determine the overall properties of the biodiesel fuel. In turn, the properties of the various fatty esters are determined by the structural features of the fatty acid and the alcohol moieties that comprise a fatty ester. Structural features that influence the physical fuel properties of a fatty ester molecule include chain length, degree of unsaturation and branching of the chain. Important fuel properties of biodiesel that are influenced by the fatty acid profile and, in turn, by the structural features of the various fatty esters include ignition quality, heat of combustion, cold flow, oxidative stability, exhaust emissions, viscosity and lubricity.

Better understanding of the structure-physical property relationships in FA esters is of particular importance when choosing vegetable oils that will give the desired biodiesel quality. By having accurate knowledge of the influence of the molecular structure on the properties determined, the composition of the oils and the alcohol used can both be selected to give the optimal performance. Improving cold-temperature flow characteristics requires a fuel with low saturated fatty acid levels, whereas increasing oxidative stability and reducing NOx emissions requires decreasing the amounts of unsaturated and polyunsaturated fatty acids. Additionally, the ignition quality (as measured by cetane number) is also adversely affected by increased unsaturation. Given the antagonistic requirements between cold-temperature flow characteristics on the one hand and oxidative stability, NOx emissions and cetane number on the other, there is no fatty acid profile that will provide a fuel for which all these parameters are optimal. However, a very good compromise can be reached by considering a fuel high in the mono-unsaturated fatty acids, such as oleate or palmitoleate and low in both saturated and polyunsaturated fatty acids. In this paper, the 
relationship between the chemical structure and physical properties of vegetable oil esters is reviewed and engineering fatty acid profiles to optimize biodiesel fuel characteristics is highlighted.

\section{Correlation between the chemical structure of the oil and its kinematic viscosity}

Kinematic viscosity and density are two important parameters required by biodiesel and diesel fuel standards because of being key fuel properties for diesel engines. In a diesel engine, the liquid fuel is sprayed into compressed air and atomized into small drops near to the nozzle exit. The liquid fuel, usually, forms a coneshaped spray at the nozzle exit and its viscosity affects the atomization quality, size of fuel drop and penetration (Alptekin and Canakci, 2008). Fuels with high viscosity tend to form larger droplets on injection which can cause poor fuel atomization during the spray, increases the engine deposits, needs more energy to pump the fuel and wears fuel pump elements and injectors. High viscosity consequently leads to poor combustion, increased exhaust smoke and emissions (Knothe and Steidley, 2005a). High viscosity also causes more problems in cold weather, because viscosity increases with decreasing temperature (Tat and van Gerpen, 1999; Joshi and Pegg, 2007).

Fuels with low viscosity may not provide sufficient lubrication for the precision fit of fuel injection pumps, resulting in leakage or increased wear (Knothe and Steidley, 2005a). The higher heating value (HHV) is an important property defining the energy content and thereby efficiency of fuels, such as vegetable oils and biodiesels. The HHV of biodiesel is approximately $10 \%$ less than that of petrodiesel (41 MJ/kg compared to $\sim 46 \mathrm{MJ} / \mathrm{kg}$ ). The higher heating value of a fuel increases with increasing carbon number in fuel molecules and also increases as the ratio of carbon and hydrogen to oxygen and nitrogen increases (Demirbas 1997). Demirbas (2008) studied the correlation between viscosity and higher heating value (HHV) by performing a linear least square regression analysis and argued that there is high regression between the higher heating value and the viscosity values of vegetable oils and their methyl esters; the HHVs of vegetables oils and biodiesels increase with viscosity.

The viscosity of a transesterified oil, i.e., biodiesel, is about an order of magnitude lower than that of the parent oil as shown in Table 1 (Knothe, 2005b). High viscosity is the major fuel property which explains why neat vegetable oils have been largely abandoned as alternative diesel fuel (Dunn and Knothe, 2001). The difference in viscosity between the parent oil and the alkyl ester derivatives can be used to monitor biodiesel production (De Filippis, et al., 1995; Knothe, 2000). Dynamic and kinematic viscosity data (which are related by density as a factor) of some individual fatty compounds are available in the literature. Kinematic viscosity (at $40^{\circ} \mathrm{C}$ ), however, is the parameter required by biodiesel and petrodiesel standards. However, the data in the literature vary not only by dynamic vs. kinematic viscosity but also by temperature with some data being not obtained at $40^{\circ} \mathrm{C}$. Kinematic viscosity at $40{ }^{\circ} \mathrm{C}$ is limited to $3.5-5.0 \mathrm{~mm}^{2} / \mathrm{s}$ in the European biodiesel standard norms. The American specifications allow a broader range of values $\left(1.9-6.0 \mathrm{~mm}^{2} / \mathrm{s}\right)$. The corresponding limit for petrodiesel fuel is considerably lower (2.0 - 4.5) (Knothe, 2006).

Viscosity increases with chain length (number of carbon atoms). This holds also for the alcohol moiety because the viscosity of ethyl esters is slightly higher than that of methyl esters (Knothe and Steidley, 2005a). Geller and Goodrum (2000) reported that viscosity of pure and saturated TAGs of 6:0 to 18:0 correlated with the carbon number in a second order polynomial fashion. As the lengths of the acid and alcohol segments in the ester molecules increased, so did the degree of random intermolecular interactions and consequently the viscosity. The effect becomes more evident at lower temperatures, where the molecular movements are even more restricted (Rodrigues et al., 2006).

Viscosity increases with increasing degree of saturation. Factors such as double-bond configuration influence viscosity; cis double-bond configuration giving a lower viscosity than trans as illustrated in

Table 1: Kinematic viscosity $\left(40{ }^{\circ} \mathrm{C} ; \mathrm{mm}^{2} / \mathrm{s}\right)$ measurements for common oils and fats and their methyl esters

\begin{tabular}{lcc}
\hline & Oil/Fat & Methyl Ester \\
\hline Corn oil & 34.9 & 4.52 \\
Cottonseed oil & 33.5 & 3.75 \\
Linseed oil & 27.2 & 2.83 \\
Peanut oil & 39.6 & 3.94 \\
Safflower oil & 31.3 & 4.03 \\
Sesame oil & 35.5 & 3.04 \\
Soybean oil & 32.6 & 4.08 \\
Sunflower oil & 37.1 & 4.16 \\
Tallow (Beef) & 51.2 & 5.16 \\
\hline Source: Oil/Fat: Adapted from Knothe, 2005b. Methyl ester: Adapted from
\end{tabular}

Source: Oil/Fat: Adapted from Knothe, 2005b. Methyl ester: Adapted from Demirbas, 2008 
Table 2. This is of significance for the use of 'waste' oils (such as frying oils) as biodiesel, as they usually are partially hydrogenated and frequently contain higher amounts of trans fatty acid chains (Knothe and Steidley, 2005a). Double-bond position affects viscosity less; terminal double bonds have a comparatively small viscosity-reducing effect (Knothe, 2005b).

Table 2 compares the kinematic viscosity of several monounsaturated fatty acid methyl esters, among them cis and trans isomers of methyl octadecenoate with the unsaturation in three different positions in the chain. For all neat trans isomers of methyl octadecenoate, the kinematic viscosity exceeded the upper limit of $5 \mathrm{~mm}^{2} /$ $\mathrm{s}$ prescribed in the European biodiesel standard but was within the upper limit of $6 \mathrm{~mm}^{2} / \mathrm{s}$ in the American biodiesel standard.

It has been reported by Rodrigues et al. (2006) that one double bond was shown to increase viscosity, whereas two or three double bonds caused a decrease in the viscosity. By comparing the viscosities of methyl stearate and methyl oleate, they observed that the presence of one double bond did increase the viscosity. In contrast, two or three double bonds (methyl linoleate and methyl linolenate, respectively) reduced the viscosity, as compared with the results for methyl stearate. They argued that the presence of one carboncarbon double bond in the structure of oleates gave rise to stronger intermolecular interactions between the p electrons of the double bonds. This kind of interaction may have occurred because the spatial geometry of the cis configuration of the one double bond of the oleate still allowed a close packing between the molecules. Obviously, strong orbital interactions could not be found between the stearate molecules, where only weaker van der Waals interactions were possible. On the other hand, the interactions between the $p$ orbitals in linoleates and linolenates were reduced because of the spatial geometry of these molecules, where the alternate double bonds, all in cisconformation, led to a configuration like a coil, hindering the approach of the $\mathrm{sp} 2$ atoms from the double bonds of neighboring molecules. These effects should account for the differences in viscosity observed.

Branching in the ester moiety can alter viscosity, although to a lesser extent than unsaturation. Branching reduces the interactions between carbon chains by hindering the approach of neighboring molecules, as verified by Lee et al. (1995).
Table 2: Kinematic viscosity $\left(40{ }^{\circ} \mathrm{C} ; \mathrm{mm}^{2} / \mathrm{s}\right)$ of some unsaturated acid fatty methyl esters including isomers of methyl octadecenoate

\begin{tabular}{lll}
\hline $\begin{array}{l}\text { Chain length and double } \\
\text { bond position }\end{array}$ & $\begin{array}{l}\text { Double bond configuration } \\
\text { cis }\end{array}$ & \begin{tabular}{c} 
trans \\
\hline $14: 1 ; \Delta 9$
\end{tabular} \\
$16: 1 ; \Delta 9$ & 2.73 & nd \\
$18: 1 ; \Delta 6$ & 3.67 & nd \\
$18: 1 ; \Delta 9$ & 4.64 & 5.51 \\
$18: 1 ; \Delta 11$ & 4.51 & 5.86 \\
$18: 1 ; \Delta 9,12-\mathrm{OH}$ & 4.29 & 5.41 \\
$18: 2 ; \Delta 9,12$ & 15.44 & nd \\
$20: 1, \Delta 11$ & 3.65 & 5.33 \\
$22: 1, \Delta 13$ & 5.77 & nd \\
Source: Knothe and Steidley, 2005a & 7.33 & nd \\
\hline
\end{tabular}

Systematic (trivial names) of compounds in this table: methyl 9(Z)tetradecenoate (methyl myristoleate), methyl $9(Z)$-hexadecenoate (methyl palmitoleate), methyl 6(Z)-octadecenoate (methyl petroselinate), methyl 6(E)-octadecenoate (methyl petroselaidate), methyl 9(Z)-octadecenoate (methyl oleate), methyl 9(E)-octadecenoate (methyl elaidate), methyl 11(Z)octadecenoate (methyl cis-vaccenate), methyl 11(E)-octadecenoate (methyl vaccenate), methyl 12-hydroxy- $9(Z)$-octadecenoate (methyl ricinoleate), methyl 9(E),12(E)-octadecadienoate (methyl linolelaidate), methyl 11(Z)eicosenoate, methyl 13(Z)-docosenoate (methyl erucate). nd = not determined

In a homologous series of compounds, viscosity increases directly with the molecular weight. Thus, viscosity increases with higher contents of high molecular compounds like unreacted glycerides or polymers, which can be found in used frying oil (Gunstone, 2002).

The presence of hydroxyl groups in the molecule, as in castor oil, also increases the viscosity. This is of significance for the production of castor oil-based biodiesel, a fuel that in its neat form exceeds all kinematic viscosity specifications in biodiesel standards due to its high content of ricinoleic acid (Knothe and Steidley, 2005a).

There are several reports in the literature on the kinematic or dynamic viscosity of fatty acid esters at various temperatures. The viscosity of oil is temperature dependent; rate of flow increases as the temperature increases (Gunstone, 2002). Wang and Briggs (2002) studied viscosity of soybean oils with modified fatty acid composition. The viscosity was expressed as:

\section{$\mu=A e(E a / R T)$}

where, $\mathrm{R}$ is the universal gas constant, $\mathrm{T}$ is temperature in Kelvin and Ea is the activation energy. The concept of effective carbon number was used to describe acyl chain length and degree of unsaturation and was correlated with viscosity and Ea. Linear relationships 
were established indicating that the more the saturation or the longer the fatty acyl chains, the more viscous the oil and the faster the viscosity changes with temperature. Further empirical approaches for predicting biodiesel viscosity at various temperatures were carried out by Tangsathitkulchai et al. (2004) and Krisnangkura et al. (2006).

Generally, fatty acid methyl esters have a Newtonian behavior above a temperature of about $5^{\circ} \mathrm{C}$. Below this temperature, they present a pseudoplastic behavior (Srivastava and Prasad, 2001). Methyl esters also exhibit a thixotropic behaviour. The decrease in the apparent viscosity of methyl esters with increase in temperature is approximately exponential. The results obtained by Srivastava and Prasad (2001), with methyl esters from soybean and mustard seed oils, were also confirmed by Rodrigues et al. (2006) who also reported that this high viscosity at lower temperatures could be a result of micro-crystal formation and would cause serious problems in fuel lines and in engine filters. Tate et al. (2006) determined the viscosities of three biodiesel fuels (canola and soy methyl esters, ethyl esters of fish oil) using a Saybolt viscometer at temperatures from $20^{\circ} \mathrm{C}$ to $300^{\circ} \mathrm{C}$. Using the measured densities over the same temperature range, the dynamic viscosities were obtained.

An index termed the low-temperature viscosity ratio (LTVR) was proposed by Knothe and Steidley (2007) to evaluate individual compounds, but also mixtures by their low-temperature viscosity behavior. To determine this index, the kinematic viscosity value at 0 ${ }^{\circ} \mathrm{C}$ of a compound is divided by the kinematic viscosity value at $40^{\circ} \mathrm{C}$

$$
L T V R=\eta_{0} / \eta_{40}
$$

The LTVR can be seen as a simplified index of change of kinematic viscosity with temperature compared to the viscosity index (VI) which is commonly determined by measuring the viscosity at $40{ }^{\circ} \mathrm{C}$ and $100{ }^{\circ} \mathrm{C}$ by means of an equation given in standards such as ASTM D2270. The low-temperature viscosity behavior of biodiesel, its components, related fatty materials and blends of fatty compounds, as well as blends with petrodiesel were investigated. A variety of fatty esters was studied neat and in blends with petrodiesel.

Table 3 gives low-temperature kinematic viscosity data of petrodiesel and biodiesel fuels. Table 4 gives kinematic viscosity data for common fatty acid methyl
Table 3: Low-temperature kinematic viscosity $\left(\mathrm{mm}^{2} / \mathrm{s}\right)$ data of petrodiesel and biodiesel fuels

\begin{tabular}{ccc}
\hline Temperature $\left({ }^{\circ} \mathrm{C}\right)$ & Biodiesel & Petrodiesel \\
\hline 40 & 4.15 & 2.90 \\
35 & 4.64 & 3.25 \\
30 & 5.15 & 3.64 \\
25 & 5.76 & 4.08 \\
20 & 6.43 & 4.55 \\
15 & 7.52 & 5.31 \\
10 & 8.67 & 6.21 \\
5 & 10.47 & 7.23 \\
0 & 11.75 & 8.58 \\
-5 & nd & 10.81 \\
-10 & nd & nd \\
LTVR & 2.83 & 2.96 \\
\hline
\end{tabular}

Source: Knothe and Steidley, 2007

esters, methyl decanoate (C10:0), methyl laurate (C12:0), methyl myristoleate (C14:1), methyl palmitoleate (C16:1), methyl oleate (C18:1), methyl linoleate (C18:2), methyl linolenate $(\mathrm{C} 18: 3)$, methyl ricinoleate $(\mathrm{C} 18: 1,12-$ $\mathrm{OH})$ as well as, for comparison purposes, two alcohols (1-decanol and oleyl alcohol), as well as a triacylglycerol (triolein).

The blends showed a behavior closer to that of petrodiesel than of biodiesel or its neat components. Esters with shorter fatty acid chains, but longer alcohol moieties display somewhat lower viscosities than esters with longer fatty acid chains and shorter alcohol moieties. Saturated esters with high melting points have only little influence on kinematic viscosity at lower temperatures and at concentrations observed in many common vegetable oils. The presented data can be used for assessing fatty esters in terms of enriching them in biodiesel for the sake of improving fuel properties. Furthermore, the data presented can be used for predicting or verifying the viscosity of yet non-investigated compounds, as well as of mixtures.

Other literature dealt with predicting the kinematic viscosity of biodiesel. Predicting the viscosities of biodiesel fuels from the knowledge of their fatty acid composition applying a logarithmic equation was investigated by Allen et al. (1999) and Rabelo et al. (2000) and verified by further studies (Noor Azian et al., 2001; Boyak et al., 2002).

Beside the prediction of the viscosity in biodiesel, an attempt for determining a blending rule for the viscosity of the blends of a general type of biodiesel with petroleum diesel was made by Yuan et al. (2005). However, a generalized equation for predicting the 
Table 4: Low-temperature kinematic viscosity $\left(\mathrm{mm}^{2} / \mathrm{s}\right)$ data of saturated and unsaturated fatty compounds

\begin{tabular}{|c|c|c|c|c|c|c|c|c|c|c|c|}
\hline \multirow{2}{*}{ Temp. $\left({ }^{\circ} \mathrm{C}\right)$} & \multicolumn{8}{|c|}{ Fatty acid methyl ester } & \multicolumn{2}{|c|}{ Alcohols } & \multirow{2}{*}{ Ttriolein } \\
\hline & $\mathrm{C} 10: 0$ & $\mathrm{C} 12: 0$ & $\mathrm{C} 14: 1$ & $\mathrm{C} 16: 1$ & $\mathrm{C} 18: 1, \Delta 9 \mathrm{c}$ & $\mathrm{C} 18: 2$ & $\mathrm{C} 18: 3$ & $\mathrm{C} 18: 1,12-\mathrm{OH}$ & $\mathrm{C} 10: 0$ & $\mathrm{C} 18: 1$ & \\
\hline 40 & 1.71 & 2.41 & 2.73 & 3.67 & 4.51 & 3.65 & 3.09 & 15.29 & 8.01 & 16.92 & 38.44 \\
\hline 35 & 1.87 & 2.69 & 3.04 & 3.96 & 5.08 & 4.08 & 3.32 & 18.58 & 9.53 & 20.69 & 46.18 \\
\hline 30 & 2.05 & 2.95 & 3.37 & 4.42 & 5.72 & 4.53 & 3.88 & 23.83 & 11.38 & 25.64 & 58.02 \\
\hline 25 & 2.23 & 3.29 & 3.71 & 4.94 & 6.44 & 5.03 & 4.07 & 29.77 & 13.18 & 29.57 & 71.04 \\
\hline 20 & 2.45 & 3.63 & 4.13 & 5.56 & 7.33 & 5.61 & 4.57 & 37.07 & 16.26 & 37.65 & 86.82 \\
\hline 15 & 2.71 & 4.07 & 4.73 & 6.38 & 8.51 & 6.43 & 5.14 & 49.47 & 20.86 & 49.27 & 113.51 \\
\hline 10 & 3.10 & 4.79 & 5.35 & 7.33 & 9.91 & 7.30 & 5.53 & 64.74 & 25.64 & 62.11 & 145.71 \\
\hline 5 & 3.49 & 5.45 & 6.13 & 8.55 & 1.66 & 8.47 & 6.59 & 91.92 & 33.19 & 82.26 & 200.89 \\
\hline 0 & 4.04 & nd & 7.01 & 10.15 & 14.03 & 9.84 & 7.33 & 123.83 & nd & nd & 261.27 \\
\hline-5 & 4.68 & - & 8.37 & 12.19 & 17.22 & 11.80 & 8.81 & 182.36 & - & - & 376.35 \\
\hline-10 & 5.40 & - & 9.92 & 14.77 & 21.33 & 14.10 & 10.19 & 271.50 & - & - & nd \\
\hline LTVR & 2.37 & - & 2.57 & 2.76 & 3.11 & 2.70 & 2.37 & 8.10 & - & - & 6.80 \\
\hline
\end{tabular}

Source: Knothe and Steidley, 2007

viscosities for blends was later given by Alptekin and Canakci (2008). The equation correlated the viscosity as a function of biodiesel fraction by empirical seconddegree equation. Because, a linear equation does not fit the data well, then it was needed to use higherdegree equation. The general form of the equation as a function of biodiesel fraction is given by:

$\eta=A x^{2}+B x+C$

where $\eta$ is the kinematic viscosity $\left(\mathrm{mm}^{2} / \mathrm{s}\right), \mathrm{A}, \mathrm{B}, \mathrm{C}$ are coefficients which are different for different oils and $\mathrm{x}$ is the biodiesel fraction.

This physical property can also be used to restrict the FA profile. For example, shorter-chain FA are excluded by the relatively high minimum value for kinematic viscosity in EN 14214. Although the minimum value for kinematic viscosity prescribed in ASTM D 6751 overlaps most petrodiesel fuels, the high minimum kinematic viscosity value for biodiesel prescribed in EN 14214 is higher than that of many petrodiesel fuels, underscoring the feedstock-restrictive nature of the EN 14214 limit. Also, biodiesel fuels derived from used frying oils tend to possess higher viscosity than those from most vegetable oils, owing to their higher content of trans FA and saturated, or, more generally speaking, less unsaturated FA. An upper limit of $5 \mathrm{~mm}^{2} / \mathrm{s}$ for kinematic viscosity in biodiesel standards may exclude some frying oils as feedstock (Knothe, 2006).

Correlation between the chemical structure of the oil and its density

Density is a key fuel property, which directly affects the engine performance characteristics. Many performance characteristics, such as cetane number and heating value, are related to the density (Tat and van Gerpen, 2000). Fuel density affects the mass of fuel injected into the combustion chamber and thus, the air-fuel ratio. This is because fuel injection pumps meter fuel by volume not by mass and a denser fuel contains a greater mass in the same volume. Thus, the changes in the fuel density will influence engine output power due to a different mass of fuel injected (Alptekin, and Canakci, 2008).

Density limits in the European EN norm are in the range of $860-900 \mathrm{~kg} / \mathrm{m}^{3}$. The ASTM norm includes no regulation on this parameter. It is argued that the determination of density is superfluous for biodiesel samples complying with all other prescribed specifications, as these fuels will inevitably have densities in the desired range. In many studies, it was observed that biodiesel's density has not changed a lot, because the densities of methanol and oil are close to the density of the produced biodiesel (Graboski and McCormik, 1998; Encinar et al., 2005).

Densities of biodiesel fuels are generally higher than those of petrodiesel, however, the energy content of which is lower both on a mass and a volume basis compared to diesel fuel (Canakci and van Gerpen, 2001). This negative property needs more fuel injected into the combustion chamber in order to gain the same power from the engine. This is an important factor increasing the fuel consumption.

Values for FAME samples depend on their fatty acid composition, as well as on their purity. On the one hand, density increases with decreasing chain length and increasing number of double bonds, explaining high values for fuels rich in unsaturated compounds, such as sunflower oil methyl ester $\left(885 \mathrm{~kg} / \mathrm{m}^{3}\right)$ or linseed 
oil methyl ester $\left(891 \mathrm{~kg} / \mathrm{m}^{3}\right)$. On the other hand, density can be decreased by the presence of low-density contaminants, such as methanol (Alptekin, and Canakci, 2008).

A widely used method for density prediction of vegetable oils was developed by Lund and discussed by Halvorsen et al. (1993). The Lund relationship is:

$\operatorname{sg}\left(15^{\circ} \mathrm{C}\right)=0.8475+0.00030 \mathrm{SV}+0.00014 \mathrm{IV}$

where sg is the specific gravity of vegetable oil at $15 \mathrm{C}$, $\mathrm{SV}$ is the saponification value, and IV is the iodine value of the oil. This equation can be used for a wide variety of oils.

A generalized method of density estimation, which was developed by Rodenbush et al. (1999), was also extended to predict oil viscosity, thereby relating these two key physical properties.

A generalized equation for predicting the density of blends was developed by Alptekin and Canakci (2008), correlating the density as a function of biodiesel fraction by empirical linear equation:

$D=A x+B$

where $\mathrm{D}$ is density $\left(\mathrm{g} / \mathrm{cm}^{3}\right)$, A and B are coefficients which are different for different oils and $\mathrm{x}$ is biodiesel fraction.

Correlation between the chemical structure of the oil and its lubricity

For two liquids of the same viscosity, if one gives lower friction, wear or scuffing, then it is said to have better (or higher) lubricity (Appledorn and Dukek, 1966 cited in van Gerpen et al., 1999). Although the viscosity of diesel fuel has been believed to be related to lubricity, many researchers believe that the lubricity of the fuel is not provided by fuel viscosity (van Gerpen et al., 1999; Anastopoulos et al., 2001).

The fuel lubricity issue is significant, because the advent of low-sulfur petrodiesel fuels and, more recently, ultralow-sulfur diesel (ULSD) fuels, as required by regulations in the United States, Europe and elsewhere, has led to the failure of engine moving parts such as fuel injectors and pumps, because they are actually lubricated by the diesel fuel itself (Goodrum and Geller, 2005). The poor lubricity of lowsulfur petrodiesel requires additives or blending with another fuel of sufficient lubricity to regain lubricity. The reason for the poor lubricity of low-sulfur petrodiesel is not the removal of the sulfur-containing compounds but rather that polar compounds with other heteroatoms such as oxygen and nitrogen are also reduced during the desulfurization process (Knothe and Steidley, 2005b). Biodiesel has superior lubricity (which reduces engine wear) over petroleum diesel fuel (Knothe, 2005d). Lubricity results of biodiesel and petroleum diesel using industry test methods indicate that there is a marked improvement in lubricity when biodiesel is added to conventional diesel fuel (Anastopoulos et al., 2001). Research conducted using 1-2 percent blends of biodiesel mixed with petroleum diesel fuel revealed an increase in lubricity. HFRR test procedures using a two percent blend of biodiesel reduced the wear scar diameter by nearly 60 percent (from 513 to 200 microns) (Knothe and Steidley, 2005b).

The lubricity of low-level blends $(1 \%-2 \%)$ of biodiesel with low-lubricity petrodiesel is largely caused by free fatty acid and monoacylglycerol contaminants present in the biodiesel (Schumacher, 2005). Hu et al. (2005) reported that monoacylglycerols and methyl esters especially enhance biodiesel lubricity, more so than free fatty acids and diacylglycerols, whereas triacylglycerols had almost no effect. These results are in partial accordance with the results presented by Knothe and Steidley.

An advantage of biodiesel compared to lubricityenhancing additives is that biodiesel inherently possesses fuel properties competitive and compatible with conventional petroleum-based diesel fuel, which other additives usually do not possess (Knothe, 2005c). Lubricity has not been included as specification in biodiesel standards despite the definite advantage of biodiesel versus petrodiesel with respect to this fuel property (Knothe, 2005c).

It would be helpful to know whether there is a correlation between the fatty acid-type and content on lubricity of particular biobased oils. If this correlation is known, better lubricants can be developed from this information. Unsaturated acids exhibited better lubricity than saturated species. Ethyl esters had improved lubricity compared to methyl esters (Kenesey and Ecker, 2003). Oxidized biodiesel showed improved lubricity, compared to its non-oxidized counterpart (Wain and Perez, 2002). Sarin et al. (2007) pointed that the variation in the lubricating performance of biodiesel could be better linked to its residual acidity than to variation in fatty 
acid composition. It was argued by Fernando et al. (2007) that analyses did not indicate any significant correlation between fatty acid content or degree of saturation and lubricity. However, they reported that crude oils had a significantly better lubricity than their fatty acid methyl esters. This indicates that removal of glycerol molecules from the triglycerides along with apparent reduction in molecular size has a significant effect on the lubricity.

Studies on castor oil suggested that its uniquely high level of the hydroxy fatty acid ricinoleic acid may impart increased lubricity to the oil and its derivatives as compared to other vegetable oils. Likewise, the developing oilseed Lesquerella may also increase diesel lubricity through its hydroxy fatty acid composition (Goodrum and Geller, 2005). Castor is the only commercial source of vegetable oil containing hydroxylated fatty acids. Also significant, is that fact that one of these fatty acids, ricinoleic acid $(\mathrm{C} 18: 0, \mathrm{OH})$, comprises approximately 88-90 \% of the oil produced by castor (Da Silva Ramos et al., 1984). Ricinoleic acid is a complex fatty acid which contains both a double bond and a hydroxyl group. Castor oil also contains trace quantities of dihydroxystearic acid $(\sim 0.7 \%)$ which has two hydroxyl groups. Similarly, the developing crop plant Lesquerella also produces hydroxylated fatty acids. The primary fatty acid in Lesquerella oil is Lesquerolic acid, a hydroxy arachidonic acid (C20:1, OH). This acid can account for up to $69 \%$ of total fatty acid composition in this plant. Lesquerella can also produce densipolic acid $(\mathrm{C} 18: 2, \mathrm{OH})$, auricolic acid $(\mathrm{C} 20: 2, \mathrm{OH})$ and even traces of ricinoleic acid $(\mathrm{C} 18: 0$, $\mathrm{OH})$ (Hayes et al., 1995). Hydroxyl functionality is rare in plant oils and affords these oils some interesting chemical properties.

Lubricity analysis by High-Frequency Reciprocating Rig (HFRR) shows that castor oil methyl ester performs quite well as a lubricity enhancer for diesel fuel at concentrations less than $1.0 \%$ (Goodrum and Geller, 2005). This is in general agreement with the preliminary castor fatty acid methyl ester results of Drown et al. (2001). Many recent studies investigated the technical feasibility of castor oil in producing biodiesel (Cvengros et al., 2006; Meneghetti et al., 2006a, b; Scholz and da Silva, 2008). The role of biotechnological tools in the genetic improvement of castor was highlighted in a review by Sujatha et al. (2008).

\section{Correlation between the chemical structure of the oil and its cetane number}

The CN of a diesel fuel is a relative measure of the interval between the injection of the fuel into the cylinder and the onset of auto-ignition, i.e. the ignition delay (ID) time. The shorter the ID time, the higher the $\mathrm{CN}$ and vice versa. High cetane numbers signify only short delays between fuel injection and ignition and thus guarantee good cold start behavior and a smooth run of the engine. Fuels with low cetane numbers tend to cause diesel knock and show increased gaseous and particulate exhaust emissions because of incomplete combustion (Knothe et al., 1998).

Standards have been established worldwide for $\mathrm{CN}$ determination, for example, ASTM D613 in the United States and internationally, the International Organization for Standardization (ISO) standard ISO 5165. In the ASTM standard, hexadecane and HMN are the reference compounds. The standard ASTM D975 for conventional DF requires a minimum $\mathrm{CN}$ of 40, whereas the standards for biodiesel prescribe a minimum of 47 (ASTM D6751) or 51 (European standard pr EN14214). Due to the high CN of many fatty compounds, which can exceed the cetane scale, the term "lipid combustion quality number" for these compounds was suggested (Knothe, 2005d).

The two reference compounds on the cetane scale show that $\mathrm{CN}$ decreases with decreasing chain length and increasing branching. However, branched esters derived from alcohols such as iso-propanol have $\mathrm{CN}$ that are competitive with methyl or other straight-chain alkyl esters. Thus, one long straight chain suffices to impart a high $\mathrm{CN}$ even if the other moiety is branched. Branched esters are of interest because they exhibit improved low-temperature properties (Knothe et al., 2003). Disadvantages of the branched esters are the higher price of the alcohol and the changes needed in the transesterification process yielding the branched esters.

Unsaturation in the fatty acid chain was again the most significant factor causing lower cetane numbers (Knothe et al., 2003). The more saturated the molecules, the higher the $\mathrm{CN}$ (Geller and Goodrum, 2004). A high value of $\mathrm{CN}$ was observed in saturated FAME such as palmitate and stearate, while the $\mathrm{CN}$ is in the medium range in mono-unsaturated FAME. Bangboye and Hansen (2008) verified that $\mathrm{CN}$ follows the same trend in the composition of the FAME compounds in all the feedstock used. It was observed that a feedstock that 
is high in saturated fatty esters has a high $\mathrm{CN}$, while feedstock predominant in unsaturated fatty acid have lower $\mathrm{CN}$ values. This agrees with previous reports by Harrington (1986), van Gerpen (1996) and Knothe et al. (2003). This suggests a profound effect of fatty acid composition on the $\mathrm{CN}$ of the biodiesel.

A wide variation in the values of the $\mathrm{CN}$ for biodiesel has been reported. The values of $\mathrm{CN}$ of soybean oilderived biodiesel ranged from 45 to 60 , while those of rapeseed oil-derived biofuel ranged from 48 to 61.2 (Bangboye and Hansen, 2008). Determination of the $\mathrm{CN}$ of a fuel by an experimental procedure is a tedious job for the upcoming biodiesel production industry. One of the ways of solving the problem of $\mathrm{CN}$ determination is to develop models to predict the $\mathrm{CN}$ when some parameters are known. Since the fatty acid composition of base oil predominantly affects the $\mathrm{CN}$ of the biodiesel produced from it, models can be developed relating $\mathrm{CN}$ to the composition of FAME.

Ramadhas et al. (2006) used artificial neural network (ANN) models to predict the $\mathrm{CN}$ of some fuels based on their FAME composition (Ramadhas et al., 2006). The FAME composition of biodiesel and the experimental $\mathrm{CN}$ values were used to train the networks. The fatty acid composition, in percentage of various esters in pure form, as well as mixtures of esters (biodiesel) and their experimental $\mathrm{CN}$, were taken into account for developing their model.

Bangboye and Hansen (2008) proposed an equation for predicting the $\mathrm{CN}$ of biodiesel based on the FAME compositions of the vegetable oil used for biodiesel production (Table 5). The developed equation was shown to predict, effectively, the $\mathrm{CN}$ of the biodiesel based on its FAME composition.

Correlation between the chemical structure of the oil and its oxidative stability

Oxidative stability is one of the major issues affecting the use of biodiesel because the nature of biodiesel makes it more susceptible to oxidation or auto-oxidation during long-term storage than conventional petrodiesel. Due to their chemical composition, fatty acid methyl esters are more sensitive to oxidative degradation than fossil diesel fuel especially those esters containing a high content of twice and morefold unsaturated esters, as the methylene groups adjacent to double bonds have turned out to be particularly susceptible to radical attack as the first step of fuel oxidation (Knothe, 2006).
Table 5: Cetane number $(\mathrm{CN})$ of pure fatty acid methyl esters

\begin{tabular}{ll}
\hline Lauric acid & 61.1 \\
Myristic acid & 69.9 \\
Palmitic acid & 74.4 \\
Stearic acid & 76.3 \\
Oleic acid & 57.2 \\
Linoleic acid & 36.8 \\
Linolenic acid & 21.6 \\
\hline
\end{tabular}

Source: Bangboye and Hansen (2008).

The formed hydroperoxides may polymerise with other free radicals to form insoluble sediments and gums, which are associated with fuel filter plugging and deposits within the injection system and the combustion chamber. These changes can compromise fuel quality with respect to effects on kinematic viscosity (v), acid value (AV) and cetane number (CN) (Du Plessis et al., 1985; Bondioli et al., 1995; Thompson et al., 1998; Monyem and van Gerpen, 2001; Dunn, 2008), while increases in peroxide value (PV) generally depends on the presence of oxygen (Dunn, 2002). The increased acidity and increased peroxide value as a result of oxidation reactions can also cause the corrosion of fuel system components, hardening of rubber components and fusion of moving components (Tang et al., 2008).

Oxidation of fatty compounds has been discussed extensively in the literature. Unsaturation in the fatty acid chain is the structural basis of the oxidation mechanisms. Unsaturated fatty compounds are generally more susceptible to oxidation than saturated compounds. The rate of oxidation depends on the number and location of allylic methylene positions (adjacent to the double bond) on the "backbone" of olefinic compounds. With respect to long chain fatty acid methyl ester (FAME), polyunsaturated esters are significantly more vulnerable to autoxidation than monounsaturated esters because they contain more allylic methylene positions. As a result, soybean methyl ester (SME) is significantly more prone to autooxidation than petrodiesel (Dunn, 2008).

The rates of oxidation of unsaturated fatty acids or esters can vary considerably. The understanding of oxidation is complicated by the fact that fatty acids usually occur in complex mixtures, with minor components in these mixtures catalyzing or inhibiting oxidation. This observation affects biodiesel because usually significant amounts of esters of oleic, linoleic and linolenic acids, as well as minor components which may affect oxidation are present (Knothe, 2007). Photo- 
oxidation is more rapid than autoxidation by several orders of magnitude. For oleate, photo-oxidation is about 30,000 times more rapid and for linoleate and linolenate this value is 1500 and 900 , respectively. The relative rates of autoxidation of purified esters of oleic acid (C18:1):linoleic acid (C18:2):linolenic acid (C18:3) were reported to be 1:41:98 as compared by oxygen absorption measurements (Dunn, 2008).

A European standard (EN 14112) using a Rancimat apparatus has been established for inclusion of an oxidative stability parameter in the European biodiesel standard (EN 14214). The biodiesel standard EN 14214 calls for determining oxidative stability at $110^{\circ} \mathrm{C}$ with a minimum induction period of $6 \mathrm{~h}$ by the Rancimat method (Knothe, 2007). In 2006, ASTM added an oxidation stability standard (ASTM D6751-07) of a $3 \mathrm{~h}$ minimum induction period (IP) as measured using the Rancimat test EN14112 (Dunn, 2008; Tang et al., 2008).

Factors which influence the oxidative stability of biodiesel include fatty acid composition, natural antioxidant content, the level of contaminants and the conditions of fuel storage such as temperature, exposure to light and air and tank material of construction. Leung et al. (2006) studied experimentally the characteristics of the degradation of biodiesel under different storage conditions, with regular monitoring of the samples over a period of 52 weeks. It was concluded that temperature and air exposure are two important factors affecting the degradation of biodiesel. High temperature together with air exposure greatly increases the biodiesel degradation rate. The temperature or air exposure alone, however, had little effect on biodiesel degradation. Water content in biodiesel will enhance biodiesel degradation due to hydrolysis but its effect is much less than the above two factors. Similar results were reported by Bouaid et al. (2007).

The possibility of influence of the oxidation kinetics by the containing material has been demonstrated by Bondioli et al. (1995). The presence of free organic acidity is one of the factors that promote the corrosion of materials, and it is therefore important to keep this parameter under control. Biodiesel produced with the appropriate technology will minimize the presence of those molecules that could facilitate emulsification with water that may be present. Those substances include monoglycerides, diglycerides, free glycerol, phospholipids, and in the case of production processes that include alkaline catalysis, soaps (Bondioli et al., 1995; Canakci et al., 1999).
The nature of the radicals also influences the products observed and double bond geometry can also play a role. Esters composed of linoleic and linolenic acids, whose bis-allylic methylene positions are especially susceptible to oxidation. The primary oxidation products of double bonds are allylic hydroperoxides. In these species, the original double bond(s) may have shifted or undergone cis/trans isomerization. Hydroperoxides are unstable and easily form a variety of secondary oxidation products. Reactions of hydroperoxides include rearrangement to products of similar molecular weight, fission to give shorter-chain compounds (aldehydes and acids) and dimerization to give higher molecular weight materials (Knothe, 2007).

Apart from the fatty acid composition of the feedstock, also the content of natural antioxidants, such as tocopherols (vitamin E) and tocotrienols (another major form of vitamin $\mathrm{E}$ in plants) has been identified as a crucial factor for the oxidative stability of biodiesel (Knothe, 2005c). Tocopherols can reduce the rate of biodiesel oxidation by more than a factor of 10 (Canakci et al., 1999; Knothe et al., 2005). An increased understanding of the pathways involved in the synthesis of tocopherols and tocotrienols has provided transgenic strategies to manipulate the levels of these anti-oxidants in soybeans and other crops (Cahoon et al., 2003; Karunanandaa et al., 2005). Such alterations could therefore be incorporated when developing oil crops for biodiesel (Durrett et al., 2008).

The antioxidant behavior of tocopherols represents a complex phenomenon as they are efficient antioxidants at low concentrations but they gradually lose efficacy as their concentrations in the vegetable oils increase. The loss of efficacy of tocopherols, sometimes referred to as a pro-oxidant effect, is witnessed by an increase in the rate of oxidation during the induction period, despite elongation of this phase. The phenomenon is much obvious for $\alpha$-tocopherol, but is also evident for other tocopherols. In agreement with nature's wisdom, the tocopherol levels in vegetable oils seem to be close to the optimal levels needed for the stabilization of these oils. The presence of other antioxidants in the oils such as carotenoids, may synergize with tocopherols and minimize this loss of efficacy (Yanishlieva et al., 2002; Kamal-Eldin, 2006). The level of natural antioxidants in vegetable oils is affected by the refining process. Unrefined vegetable oils which still contain their natural levels of antioxidants 
usually have improved oxidative stability compared to the refined oils but do not meet other fuel requirements. Ferrari et al. (2005) observed that even though the neutralized, refined and waste frying soybean oils presented close comparable iodine values, biodiesel presented different oxidative stabilities. The biodiesel from neutralized soybean oil presented greater stability, followed by the refined and the frying waste. Due to the natural antioxidants in its composition, the neutralized soybean oil promoted a larger oxidative stability of the produced biodiesel. During the deodorization process, the vegetable oils lose part of these antioxidants; therefore the biodiesel from refined soybean oil presented a reduced stability. The thermal process degrades the antioxidants, thus the biodiesel from frying waste oil resulted in lower stability.

Bondioli et al. (2002) reported that polymers formed during storage of biodiesel in controlled conditions are soluble in oxidized biodiesel, due to its high polarity, and become insoluble only when oxidized biodiesel is mixed with diesel fuel. The physico-chemical characteristics of biobiesel treated with ozonated oil indicated the improvement of the thermal and oxidative stability (El Diwani and El Rafie, 2008).

Correlation between the chemical structure of the oil and its cold flow properties

One of the major problems associated with the use of biodiesel in countries with cold climate is poor cold flow properties, indicated by relatively high cloud points (CP) and pour points (PP) (Durrett et al., 2008). The CP, which usually occurs at a higher temperature than the PP, is the temperature at which a liquid fatty material becomes cloudy due to formation of crystals and solidification of saturates. Solids and crystals rapidly grow and agglomerate, clogging fuel lines and filters and causing major operability problems. With decreasing temperature, more solids form and the material approaches the pour point, the lowest temperature at which it will still flow. No. 2 diesel fuel (the type most used in automobiles) has CP and PP values of around -16 and $-27^{\circ} \mathrm{C}$, respectively, whereas biodiesel derived from soybeans (SME) has much higher $\mathrm{CP}$ and $\mathrm{PP}$ values, around 0 and $-2{ }^{\circ} \mathrm{C}$, respectively (Table 6). Cold flow properties of methyl and ethyl ester forms of biodiesel derived from several feedstocks are summarized in Table 6. Ransesterification does not alter the fatty acid composition of the feedstocks. Therefore, biodiesel made from feedstocks containing higher concentrations of high-melting point saturated long-chain fatty acids tends to have relatively poor cold flow properties (Dunn, 2005).

Both viscosity and crystallization temperature are physical properties that depend on the interactions between molecules. However, crystallization requires not only interaction, but also good molecular packing to reach the adequate entropy level (Rodrigues et al., 2006). The length of the FA chain was shown to have a marked influence on the crystallization temperature of the produced biodiesel (Rodrigues et al., 2006). Unsaturation also influences the crystallization temperature, since the spatial configuration of the molecule can interfere with crystal packing efficiency. Thus, molecules presenting a spatial arrangement that disrupts their packing ability will have lower crystallization temperatures (Nascimento et al., 2005). Due to its content of saturated compounds, tallow methyl ester (TME) has $\mathrm{CP}=17^{\circ} \mathrm{C}$. Another example is palm oil methyl ester, whose $\mathrm{CP}=13{ }^{\circ} \mathrm{C}$ (Table 6). In

\begin{tabular}{|c|c|c|c|c|c|c|}
\hline \multirow{2}{*}{ Oil or Fat } & \multicolumn{2}{|c|}{$\mathrm{CP}\left({ }^{\circ} \mathrm{C}\right)$} & \multicolumn{2}{|c|}{$\mathrm{PP}\left({ }^{\circ} \mathrm{C}\right)$} & \multicolumn{2}{|c|}{ CFPP $\left({ }^{\circ} \mathrm{C}\right)$} \\
\hline & Methyl Ester & Ethyl Ester & Methyl Ester & Ethyl Ester & Methyl Ester & Ethyl Ester \\
\hline Canola Oil & 1 & -1 & -9 & -6 & & \\
\hline Coconut Oil & & 5 & & -3 & & \\
\hline Linseed Oil & 0 & -2 & -9 & -6 & & \\
\hline Olive Oil & -2 & & -3 & & -6 & \\
\hline Palm Oil & 13 & 8 & 16 & 6 & & \\
\hline Safflower Oil & & -6 & -6 & -6 & & \\
\hline Soybean Oil & 0 & 1 & -2 & -4 & -2 & \\
\hline Sunflower Oil & 2 & -1 & -3 & -5 & -2 & \\
\hline Tallow (Beef) & 17 & 15 & 15 & 12 & 9 & 8 \\
\hline
\end{tabular}

Source: Adapted from Dunn, 2005 
contrast, feedstocks with relatively low concentrations of saturated long-chain fatty acids generally yield biodiesel with much lower CP and PP. Thus, feedstocks such as linseed, olive, rapeseed, and safflower oils tend to yield biodiesel with $\mathrm{CP}<0{ }^{\circ} \mathrm{C}$. It has been reported by Rodrigues et al. (2006) that more than one unsaturation in the carbon chain lowers both the crystallization temperature and the viscosity by hindering molecular packing. They showed that double bonds positioned near the ends of the carbon chain enable a more efficient packing than those found near the middle of the molecule. Nascimento et al. (2005) have studied the effects of chemical structure on the crystallization temperature using a series of branched alcohol esters. They observed that branching in the carbon chain reduces the crystallization temperature of the esters studied. Crystallization phenomena involve a high level of organization to promote nucleation. Linear esters pack efficiently into crystals and because van der Waals attractions are large, they have relatively high crystallization temperatures. Branching interferes with the crystal packing, hence decreasing the TCO (crystallization onset temperature). Branched esters showed a lower TCO (crystallization onset temperature) as determined by differential scanning calorimetry(DSC) for the isopropyl esters of soybean oil by $7-11^{\circ} \mathrm{C}$ and for the 2-butyl esters of SBO by $12-14{ }^{\circ} \mathrm{C}$ (Lee et al., 1995). The CPs and PPs were also lowered by the branched-chain esters (Table 5). For example, the CP of iso-propyl soyate was given as $-9^{\circ} \mathrm{C}$ and that of 2-butyl soyate as $-12^{\circ} \mathrm{C}$. In comparison, the $\mathrm{CP}$ of methyl soyate is $0{ }^{\circ} \mathrm{C}$.

Specifications related to low-temperature properties are included in biodiesel standards. Cloud point is the related property in ASTM D6751, but a limit is not given, rather a report is required. This is due to the strongly varying weather conditions in the United States. Cold filter plugging point (CFPP) is discussed in EN 14214. Each country can select one of two options (moderate or arctic climate) for seasonal classes (summer and winter) and modify this specification based on national meteorological data (Knothe, 2005c).

Correlation between the chemical structure of the oil and other properties

Iodine Value (IV)

Iodine number is a measure of total unsaturation within a mixture of fatty material, regardless of the relative shares of mono-, di-, tri- and polyunsaturated compounds. Whereas the American norm does not contain regulations on this parameter, iodine number is limited to d" 120 (g I2/100g) in the European specification. The IV of 120 in EN 14214 can serve to restrict certain vegetable oils as biodiesel feedstock, notably soybean oil or sunflower oil. IV restrictions can be overcome by the use of higher esters, such as ethyl or propyl, although the FA profile remains unchanged (Knothe, 2002).

\section{Acid number}

Acid number of biodiesel depends on a variety of factors. On the one hand, it is influenced by the type of feedstock used for fuel production and on its respective degree of refinement. On the other hand, acidity can also be generated during the production process, for instance, by mineral acids introduced as catalysts or by free fatty acids resulting from acid work-up of soaps. Finally, the parameter also mirrors the degree of fuel ageing during storage, as it gradually increases due to hydrolytic cleavage of ester bonds. High fuel acidity has been discussed in the context of corrosion and the formation of deposits within the engine, particularly in fuel injectors, by catalyzing polymerization in hot recycling fuel loops. However, it has been shown that free fatty acids as weak carboxylic acids pose far lower risks than strong mineral acids (Cvengros, 1998). The respective limit in the European norm is $<0.5 \mathrm{mg} \mathrm{KOH} /$ g sample, whereas the American standard was allowing slightly higher values. In 2006, the ASTM D 6751 biodiesel acid-number limit was harmonized with the European biodiesel value of 0.50 (Mahajan et al., 2006).

\section{Heating (Calorific) value}

Biodiesel fuels do not contain aromatics, but they contain methyl esters with different levels of saturation. Unsaturated esters have lower energy content on a weight basis, but due to their higher density, they have more energy per unit volume. For example, methyl stearate has a higher heating value of $40.10 \mathrm{MJ} / \mathrm{kg}$, which is $0.41 \%$ higher than that of methyl oleate $(39.93 \mathrm{MJ} / \mathrm{kg})$. However, on a volume basis (at $40{ }^{\circ} \mathrm{C}$ ), methyl stearate has an energy content of $34.07 \mathrm{MJ} / \mathrm{L}$, which is $0.7 \%$ less than that of methyl oleate $(34.32 \mathrm{MJ} / \mathrm{L})$. These differences are small enough that feedstock differences are difficult to detect in actual use (McCormick and Alleman, 2005).

\section{Future prospects}

Engineering fatty acid profiles to optimize biodiesel fuel characteristics

As reflected by the data in this study, soybean oil- 
FAME (SME) is typically composed of 80-85 wt \% total mono- and polyunsaturated FAME. Soybean oil has a high content of linoleic acid, and a lower level of linolenic acid. They are the cause of oxidative instability of this oil. Soybean lines with high levels of oleic acid and low levels of saturated and polyunsaturated fatty acids have been developed using a transgenic strategy that results in down-regulation of two genes involved in fatty acid synthesis (Buhr et al., 2002). Downregulation of the FAD2-1 gene, encoding a -12 fatty acid desaturase, prevented the conversion of oleic acid to polyunsaturated fatty acids, resulting in increased levels of oleic acid. Additionally, preventing the release of saturated fatty acids from ACP (acyl carrier protein) by down-regulating FatB gene, which encodes a palmitoyl ACP (acyl carrier protein) thioesterase, lowered the levels of saturated fatty acids. In this manner, soybean lines were generated that had oleic acid levels greater than $85 \%$ and saturated fatty acid levels less than $6 \%$, compared to wild-type levels of $17.9 \%$ and $13.1 \%$, respectively (Buhr et al., 2002). Consistent with these predictions, biodiesel synthesized from these high-oleic soybeans demonstrated improved fuel characteristics with regard to cold temperature flow properties and NOx emissions (Tat et al., 2007). For example, compared to biodiesel derived from conventional soybean oil, the $\mathrm{CP}$ was lowered from 1 to $-5^{\circ} \mathrm{C}$ and the PP from 0 to $9{ }^{\circ} \mathrm{C}$. Also, NOx emissions from the high oleic acid biodiesel were only $7.5 \%$ higher than those from No. 2 diesel fuel (compared to $13.5 \%$ higher for biodiesel derived from conventional soybeans). Further improvement in CP and PP might be obtained by engineering monounsaturated oils with shorter chain lengths. Some plant species, for example Doxantha unguis, accumulate high levels of 16:1D9 and the identification and subsequent transformation of a variant acyl ACP (acyl carrier protein) desaturase from this species into Arabidopsis and canola resulted in transgenic lines with increased levels of 16:1D9 (Bondaruk et al., 2007; Cahoon et al., 1998). Similar results were obtained in Arabidopsis plants expressing a castor ACP desaturase with enhanced activity towards 16:0 ACP (Cahoon and Shanklin, 2000). However, with both strategies, the total accumulation of 16:1D9 was low; higher levels of accumulation of 18:1D11 and 20:1 D13 suggest that elongation of the desired 16:1D9 product resulted in accumulation of these other unusual fatty acids.

Attempts to reduce $\mathrm{NO}_{x}$ exhaust emissions using reformulated biodiesel

Biodiesel produced from certain feedstocks has been shown to cause an increase in nitrogen oxides $\left(\mathrm{NO}_{\mathrm{x}}\right.$ ). Hess et al. (2007) have investigated two routes to reformulate soy-based biodiesel in an effort to reduce nitrogen oxide emissions. In one of these, soy-oil methyl esters were modified by conversion of a proportion of the cis bonds in the fatty acid chains of its methyl esters to their trans isomers. In the other approach, polyol derivatives of soybean oil were transesterified to form soy methyl polyol fatty acid esters. The $\mathrm{NO}_{\mathrm{x}}$ emissions of these modified biodiesels were then examined. The isomerization to trans configuration of the cis methyl oleate and soy-oil methyl esters increased $\mathrm{NO}_{\mathrm{x}}$ emissions by 2.7 and 1.5 percentage points, respectively, at the B20 blend level. The reasons behind this behavior are unclear. It is inconsistent with a postulate that alkyl chain linearity in a biodiesel and as promoted by trans, but not cis unsaturations, is the basis of the lower $\mathrm{NO}_{\mathrm{x}}$ emissions of saturated biodiesels. Fatty acid methyl ester preparations produced from soy polyol triglycerides decreased $\mathrm{NO}_{x}$ emissions by 5.7 percentage points, in a B20 blend, as compared to soy-derived B20. The $\mathrm{NO}_{\mathrm{x}}$ reducing effect of the polyol was linearly dependent on concentration. The oxidation process reduced the iodine value of the resultant fuel, but the $\mathrm{NO}_{\mathrm{x}}$ reduction observed was greater than would be expected based solely on the reduction in double bond content. It was concluded that polyol functionality has a $\mathrm{NO}_{\mathrm{x}}$ reducing effect on emissions.

Genetic modification has produced a soybean with a fatty acid profile high in oleic acid $(<85 \%)$ and with reduced palmitic acid $(>4 \%)$. $\mathrm{NO}_{\mathrm{x}}$ emissions from the high oleic acid biodiesel were only $7.5 \%$ higher than those from No.2 diesel fuel (compared to $13.5 \%$ higher for biodiesel derived from conventional soybeans) (Tat et al., 2007). No significant differences were found between the regular and high-oleic biodiesel for unburned hydrocarbon and smoke emissions.

\section{Biodiesel surrogates}

Synthesis of surrogate molecules has proved to be particularly useful for generating in sight of structuralactivity relationships, understanding processes and 
Table 7: Comparison of the fuel properties of FAMEs commonly found in biodiesel with the fuel properties of conventional diesel

\begin{tabular}{|c|c|c|c|c|c|}
\hline & Palmitate & Stearate & Oleate & Linoleate & Linolenate \\
\hline Number of carbon atoms & 16 & 18 & 18 & 18 & 18 \\
\hline Number of double bonds & 0 & 0 & 1 & 2 & 3 \\
\hline Cold flow properties & Worser & Worser & Similar & nd & nd \\
\hline Oxidative stability & Better & Better & Similar & Worser & Worser \\
\hline Ignition Quality & Better & Better & Better & Similar & Worser \\
\hline $\mathrm{NO}_{\mathrm{x}}$ emissions & Better & Better & Similar & Worser & Worser \\
\hline
\end{tabular}

improving the performance (Sarin et al., 2009). In order to improve upon the physico-chemical properties of biodiesel, methyl, ethyl, isopropyl and n-butyl esters of b-branched fatty acid have been synthesized, initiating from b-branched alcohols. b-branched alcohols upon oxidation gave corresponding acids, which were converted to their esters. The synthesized esters have substantially better oxidative stability, exhibited by Rancimat oxidation induction period of more than $24 \mathrm{~h}$. The cloud point of synthesized esters is $<-36{ }^{\circ} \mathrm{C}$, pour point is $<-42{ }^{\circ} \mathrm{C}$ and CFPP is $<-21^{\circ} \mathrm{C}$, which is substantially better than fatty acid methyl esters. Besides achieving the objective of better oxidative stability and improved low temperature properties, the synthesized surrogate esters have viscosity in the range of $4.2-4.6 \mathrm{cSt}$ at $40^{\circ} \mathrm{C}$, meeting the international diesel and biodiesel standards. The cetane number of synthesized esters is 62-69, which is much better than diesel and biodiesel. Therefore, fuel properties of these surrogates showed that these esters could lead towards development of better alternates to diesel fuel or jet fuel.

\section{Innovative technologies}

Most of the biodiesel that is currently made uses neat vegetable oil, methanol and an alkaline catalyst. The high value of neat vegetable oils as a food product makes production of a cost-effective fuel very challenging. However there are large amounts of lowcost oils and fats such as restaurant waste and animal fats that could be converted to biodiesel. The problem with processing these low-cost oils and fats is that they often contain large amounts of free fatty acids (FFA) that cannot be converted to biodiesel using an alkaline catalyst (Demirbas, 2007). Methodologies which allows for the use of high free fatty acid content feedstock, including used cooking oil and non-edible oils as Jatropha curcas include microwave irradiation. The results showed that application of radio frequency microwave energy offers a fast, easy route to this valuable biofuel with advantages of enhancing the reaction rate and improving the separation process (Leadbeater and Stencel, 2006; Barnard et al., 2007). It was concluded that microwave-enhanced biodiesel is not, at least, inferior to that produced by the conventional technique (Refaat et al., 2008b). However, further scale-up and economic feasibility studies are recommended.

\section{CONCLUSION}

Given the antagonistic requirements between coldtemperature flow characteristics on the one hand and oxidative stability, $\mathrm{NO}_{\mathrm{x}}$ emissions and cetane number on the other, there is no fatty acid profile that will provide a fuel for which all these parameters are optimal (Table 7). However, a very good compromise can be reached by considering a fuel high in the monounsaturated fatty acids, such as oleate or palmitoleate (16:1D9) and low in both saturated and polyunsaturated fatty acids. The presence of a single double bond greatly enhances the cold-temperature flow properties of methyl oleate compared to methyl stearate.

Data provided in this study suggested that biodiesel with high levels of methyl oleate will have excellent, if not optimal, characteristics with regard to ignition quality, $\mathrm{NO}_{\mathrm{x}}$ emissions and fuel stability. For example, while unsaturation tends to reduce the cetane number of biodiesel, that of methyl oleate is higher than the minimal biodiesel standard. Additionally, it has been estimated that biodiesel fuels with an average of 1.5 double bonds per molecule will produce an equivalent amount of $\mathrm{NO}_{\mathrm{x}}$ to conventional diesel, thus a fuel high in oleates (one double bond per molecule) should not result in higher $\mathrm{NO}_{x}$ emissions. Finally, given that polyunsaturated fatty acids have a disproportionably large effect on the auto-oxidation of biodiesel, reducing the polyunsaturated fatty acid content will improve the stability of the fuel.

Engineering fatty acid profiles to optimize biodiesel fuel characteristics offers a good solution, but requires 
further intensive investigation. Also, the synthesis of surrogate molecules has proved to be particularly useful for generating in sight of structural-activity relationships, understanding processes and improving the performance and deserves to be further studied. The use of innovative technologies, as microwave-assisted biodiesel production allows for the use of high free fatty acid content feedstock without compromising the fuel properties, however, further scale-up and economic feasibility studies are recommended.

\section{REFERENCES}

Achten, W. M. J.; Verchot, L.; Franken, Y. J.; Mathijs, E.; Singh, V. P.; Aerts, R.; Muys, B., (2008). Jatropha biodiesel production and use. Biomass Bioenerg., 32 (12), 1063-1084 (22 pages).

Allen, C. A. W.; Watts, K. C.; Ackman, R. G.; Pegg, M. J., (1999). Predicting the viscosity of biodiesel fuels from their fatty acid Ester composition. Fue1, 78 (11), 1319-1326 (8 pages).

Alptekin, E.; Canakci, M., (2008). Determination of the density and the viscosities of biodiesel-diesel fuel blends. Renew. Energ., 33 (12), 2623-2630 (8 pages).

Anastopoulos, G.; Lois, E.; Karonis, D.; Zanikos, F.; Kalligeros, S., (2001). A preliminary evaluation of esters of Monocarboxylic fatty acid on the lubrication properties of diesel Fuel. Ind. Eng. Chem. Res., 40 (1), 452-456 (5 pages).

Bangboye, A. I.; Hansen, A. C., (2008). Prediction of cetane number of biodiesel fuel from the fatty acid methyl ester (FAME) composition. Int. Agrophysics, 22 (1), 21-29 (9 pages).

Barnard, T. M.; Leadbeater, N. E.; Boucher, M. B.; Stencel, L. M.; Wilhite, B. A., (2007). Continuous-flow preparation of biodiesel using microwave heating. Energ. Fuel., 21 (3), 1777-1781 (5 pages).

Berchmans, H. J.; Hirata, S., (2008). Biodiesel production from crude Jatropha curcas L. seed oil with a high content of free fatty acids. Bioresource Tech., 99 (6), 1716-1721 (6 pages). Bondaruk, M.; Johnson, S.; Degafu, A.; Boora, P.; Bilodeau, P.; Morris, J.; Wiehler, W.; Foroud, N.; Weselake, R.; Shah, S., (2007). Expression of a cDNA encoding palmitoyl-acyl carrier protein desaturase from cat's claw (Doxantha unguiscati L.) in Arabidopsis thaliana and Brassica napus leads to accumulation of unusual unsaturated fatty acids and increased stearic acid content in the seed oil. Plant Breeding, 126 (2), 186-194 (9 pages).

Bondioli, P.; Gasparoli, A.; Bella, L. D.; Tagliabue, S., (2002). Evaluation of biodiesel storage stability using reference methods. Eur. J. Lipid Sci. Tech., 104 (12), 777-784 (8 pages).

Bondioli, P.; Gasparoli, A.; Lanzani, A.; Fedeli, E.; Veronese, S.; Sala, M., (1995). Storage stability of biodiesel. J. Am. Oil Chem. Soc., 72 (6), 699-702 (4 pages).

Bouaid, A.; Martinez, M.; Aracil, J., (2007). Long storage stability of biodiesel from vegetable and used frying oils. Fuel, 86 (16), 2596-2602 (7 pages).

Boyak, I. H.; Tekin, A.; Cizmec, M.; Javidipour, I., (2002). Viscosity estimation of vegetable oils based on their fatty acid composition. J. Food Lipids, 9 (3), 175-183 (9 pages).
Buhr, T.; Sato, S.; Ebrahim, F.; Xing, A. Q.; Zhou, Y.; Mathiesen, M.; Schweiger, B.; Kinney, A.; Staswick, P.; Clemente, T., (2002). Ribozyme termination of RNA transcripts downregulate seed fatty acid genes in transgenic soybean. Plant J., 30 (2), 155-163 (9 pages).

Cahoon, E. B.; Hall, S. E.; Ripp, K. G.; Ganzke, T. S.; Hitz, W. D.; Coughlan, S. J., (2003). Metabolic redesign of vitamin E biosynthesis in plants for tocotrienol production and increased antioxidant content. Nat. Biotech., 21 (9), 10821087 (6 pages).

Cahoon, E. B.; Shah, S.; Shanklin, J.; Browse, J., (1998). A determinant of substrate specificity predicted from the acylacyl carrier protein desaturase of developing cat's claw seed. Plant Physiol., 117 (2), 593-598 (6 pages).

Cahoon, E. B.; Shanklin, J., (2000). Substrate-dependent mutant complementation to select fatty acid desaturase variants for metabolic engineering of plant seed oils. Proceedings of the National Academy of Science USA (PNAS), 97 (22), 12350-12355.

Canakci, M., (2007). The potential of restaurant waste lipids as biodiesel feedstocks. Bioresour. Tech., 98 (1), 183-190 (8 pages).

Canakci, M.; Monyem, A.; van Gerpen, J. H., (1999). Accelerated oxidation processes in biodiesel. Am. Soc. Agr. Eng., 42 (6), 1565-1572 (8 pages).

Canakci, M.; van Gerpen, J. H., (2001). The performance and emissions of a diesel engine fueled with biodiesel from yellow grease and soybean oil. American Society of Agricultural Engineers, ASAE Annual International Meeting, Sacramento, California, USA, July 30-August 1, 2001, Paper N. 016050.

Cardone, M.; Prati, M. V.; Rocco, V.; Seggiani, M.; Senatore, A.; Vitolo, S., (2002). Brassica carinata as an alternative oil crop for the production of biodiesel in Italy: Engine performance and regulated and unregulated exhaust emissions. Environ. Sci. Tech., 36 (21), 4656-4662 (7 pages).

Carvalho, C. R.; Clarindo, W. R.; Praca, M. M.; Araujo, F. S.; Carels, N. (2008). Genome size, base composition and karyotype of Jatropha curcas L., an important biofuel plant. Plant Sci., 174 (6), 613-617 (5 pages).

Chhetri, A. B.; Watts, K. C.; Islam, M. R., (2008). Waste cooking oil as an alternate feedstock for biodiesel production. Energies, 1, 3-18 (16 pages).

Cvengros, J. (1998). Acidity and corrosiveness of methyl esters of vegetable oils. Eur. J. Lipid Sci. Tech., 100 (2), 41-44 (4 pages).

Cvengros, J.; Paligova J.; Cvengrosova, Z., (2006). Properties of alkyl esters base on castor oil. Eur. J. Lipid Sci. Tech., 108 (8), 629-635 (7 pages).

Da Silva Ramos, L. C.; Tango, J. S.; Savi, A.; Leal, N. R., (1984). Variability for oil and fatty acid composition in castorbean varieties. J. Am. Oil Chem. Soc., 61 (12), 18411843 (3 pages).

De Filippis, P.; Giavarini, C.; Scarsella, M.; Sorrentino, M., (1995). Transesterification processes for vegetable oils: A simple control method of methyl ester content. J. Am. Oil Chem. Soc., 72 (11), 1399-1404 (6 pages).

Demirbas, A., (1997). Calculation of higher heating values of biomass fuels. Fuel, 76 (5), 431-434 (4 pages).

Demirbas, A., (2007). Progress and recent trends in biofuels. Prog. Energ. Combust., 33 (1), 1-18 (18 pages). 
Demirbas, A., (2008). Relationships derived from physical properties of vegetable oil and biodiesel fuels. Fuel, 87 (89), 1743-1748 (6 pages).

Dorado, M. P.; Ballesteros, E.; Lopez, F. J.; Mittelbach M., (2004). Optimization of alkali-catalyzed transesterification of brassica carinata oil for biodiesel production. Energ. Fuel., 18 (1), 77-83 (7 pages).

Drown, D. C.; Harper, K.; Frame, E., (2001). Screening vegetable oil alcohol esters as fuel lubricity enhancers. J. Am. Oil Chem. Soc., 78 (6), 579-584 (6 pages)

Du Plessis, L. M.; de Villiers, J. B. M.; van derWalt, W. H., (1985). Stability studies on methyl and ethyl fatty acid esters of sunflower seed oil. J. Am. Oil Chem. Soc., 62 (4), $748-752$ (5 pages).

Dunn, R. O., (2002). Effect of oxidation under accelerated conditions on fuel properties of methyl soyate (biodiesel). J. Am. Oil Chem. Soc., 79 (9), 915-920 (6 pages).

Dunn, R. O., (2005). Cold Weather Properties and Performance of Biodiesel. In: Knothe, G.; van Gerpen, J.; Krahl, J., The Biodiesel Handbook, Chapter 6.3. AOCS Press, Champaign, IL, USA.

Dunn, R. O., (2008). Antioxidants for improving storage stability of biodiesel. Biofuels, Bioproducts and Biorefining, 2 (4), 304-318 (15 pages)

Dunn, R. O.; Knothe, G., (2001). Alternative diesel fuels from vegetable oils and animal fats. J. Oleo Sci., 50 (5), 415-426 (12 pages).

Durrett, T. P.; Benning, C.; Ohlrogge, J., (2008). Plant triacylglycerols as feedstocks for the production of biofuels. Plant J., 54 (4), 593-607 (15 pages).

El Diwani, G.; El Rafie, Sh., (2008). Modification of thermal and oxidative properties of biodiesel produced from vegetable oils. Int. J. Environ. Sci. Tech., 5 (3), 391-400 (10 pages).

Encinar, J. M.; Gonzalez, J. F.; Rodriguez-Reinares, A., (2005). Biodiesel from used frying oil. Variables affecting the yields and characteristics of the biodiesel. Ind. Eng. Chem. Res., 44 (15), $5491-5499$ (9 pages).

Fernando, S.; Hanna, M.; Adhikari, S., (2007). Lubricity characteristics of selected vegetable oils, animal fats, and their derivatives. Appl. Eng. Agric., 23 (1), 5-11 (7 pages).

Ferrari, R. A.; Oliveira, V. S.; Scabio, A., (2005). Oxidative stability of biodiesel from soybean oil fatty acid ethyl esters. Sci. Agr. (Piracicaba, Braz.), 62 (3), 291-295 (5 pages).

Freedman, B.; Butterfield, R. O.; Pryde, E. H., (1986). Transesterification kinetics of soybean oil. J. Am. Oil Chem. Soc., 63 (10), 1375-1380 (6 pages).

Geller, D. P.; Goodrum, J. W., (2000). Rheology of vegetable oil analogs and triglycerides. J. Am. Oil Chem. Soc., 77 (2), 111-114 (4 pages).

Geller, D. P.; Goodrum, J. W., (2004). Effects of specific fatty acid methyl esters on diesel fuel lubricity. Fuel, 83 (17-18), 2351-2356 (6 pages)

Goodrum, J. W.; Geller, D. P., (2005). Influence of fatty acid methyl esters from hydroxylated vegetable oils on diesel fuel lubricity. Bioresour. Tech., 96 (7), 851-855 (5 pages).

Graboski, M. S.; McCormik, R. L., (1998). Combustion of fat and vegetable oil derived fuels in diesel engines. Prog. Energ. Combust., 24 (2), 125-164 (40 pages).

Gunstone, F. D., (2002). Vegetable oils in food technology: Composition, Properties and Uses. Blackwell Publishing Ltd, UK.
Haas, M. J.; Foglia, T. A., (2005). Alternate feedstocks and technologies for biodiesel production. In: Knothe, G.; van Gerpen, J.; Krahl, J., The Biodiesel Handbook, Chapter 4.2. AOCS Press, Champaign, IL, USA.

Halvorsen, J. D.; Mammel Jr., W. C.; Clements, L. D., (1993). Density estimation for fatty acids and vegetable oils based on their fatty acid composition. J. Am. Oil Chem. Soc., 70 (9), 875-880 (6 pages).

Harrington, K. J. (1986). Chemical and physical properties of vegetable oil esters and their effect on diesel fuel performance. Biomass, 9 (1), 1-17 (17 pages).

Hayes, D. G.; Kleiman, R.; Phillips, B. S., (1995). The triglyceride composition, structure, and presence of estolides in the oils of Lesquerella and related species. J. Am. Oil Chem. Soc., 72 (5), 559-569 (11 pages).

Hess, M. A.; Haas, M. J.; Foglia, T. A., (2007). Attempts to reduce NOx exhaust emissions by using reformulated biodiesel. Fuel Process. Tech., 88 (7), 693-699 (7 pages).

Hu, J.; Zexue Du, Z.; Li, C.; Min, E. (2005). Study on the lubrication properties of biodiesel as fuel lubricity enhancers. Fuel, 84 (12-13), 1601-1606 (6 pages).

Joshi, R. M.; Pegg, M. J., (2007). Flow properties of biodiesel fuel blends at low temperatures. Fuel, 86 (1-2), 143-151 (9 pages).

Kamal-Eldin, A., (2006). Effect of fatty acids and tocopherols on the oxidative stability of vegetable oils. Eur. J. Lipid Sci. Tech., 108 (12), 1051-1061 (11 pages).

Karmee, S. K.; Chandna, D.; Ravi, R.; Chadha, A., (2006). Kinetics of base-catalyzed transesterification of triglycerides from pongamia oil. J. Am. Oil Chem. Soc., 83 (10), 873 877 (5 pages).

Karunanandaa, B.; Qi, Q.; Hao, M.; Baszis, S. R.; Jensen, P. K.; Wong, Y. H.; Jiang, J.; Venkatramesh, M.; Gruys, K. J.; Moshiri, F.; Post-Beittenmiller, D.; Weiss, J. D.; Valentin, H. E., (2005). Metabolically engineered oilseed crops with enhanced seed tocopherol. Metab. Eng., 7 (5-6), 384-400 (17 pages).

Kenesey, E.; Ecker, A., (2003). Oxygen bond to improve the lubricity of fuel. Tribologie und Schmierungstechnik, 50 (2), 21-26 (6 pages).

Knothe, G., (2000). monitoring a progressing transesterification reaction by fiber-optic near infrared spectroscopy with correlation to $1 \mathrm{H}$ nuclear magnetic resonance spectroscopy. J. Am. Oil Chem. Soc., 77 (5), 489-493 (5 pages).

Knothe, G., (2002). Structure indices in FA chemistry. how relevant is the iodine value?. J. Am. Oil Chem. Soc., 79 (9), 847-854 (8 pages)

Knothe, G., (2005a). Introduction. In: Knothe, G.; van Gerpen, J.; Krahl, J. The Biodiesel Handbook, Chapter 1. AOCS Press, Champaign, IL, USA.

Knothe, G., (2005b). Viscosity of biodiesel. In: Knothe, G.; van Gerpen, J.; Krahl, J. The Biodiesel Handbook, Chapter 6.2. AOCS Press, Champaign, IL, USA.

Knothe, G., (2005c). Dependence of biodiesel fuel properties on the structure of fatty acid alkyl esters. Fuel Process. Tech., 86 (10), 1059-1070 (12 pages).

Knothe, G., (2005d). Cetane numbers-heat of combustionwhy vegetable oils and their derivatives are suitable as a diesel fuel. In: Knothe, G.; van Gerpen, J.; Krahl, J. The Biodiesel Handbook, Chapter 6.1. AOCS Press, Champaign, IL, USA.

Knothe, G., (2006). Analyzing biodiesel: Standards and other methods J. Am. Oil Chem. Soc., 83 (10), 823-833 (11 pages). 
Knothe, G., (2007). Some aspects of biodiesel oxidative stability. Fuel Process. Tech., 88 (7), 669-677 (9 pages).

Knothe, G.; Bagby, M. O.; Ryan, T. W., (1998). Precombustion of fatty acids and esters of biodiesel. A possible explanation for differing cetane numbers. J. Am. Oil Chem. Soc., 75 (8), 1007-1013 (7 pages).

Knothe, G.; Matheaus, A. C.; Ryan, T. W., (2003). Cetane numbers of branched and straight-chain fatty esters determined in an ignition quality tester. Fuel, 82 (8), 971 975 (5 pages).

Knothe, G.; Steidley, K. R., (2005a). Kinematic viscosity of biodiesel fuel components and related compounds. Influence of compound structure and comparison to petrodiesel fuel components. Fuel, 84 (9), 1059-1065 (7 pages).

Knothe, G.; Steidley, K. R., (2005b). Lubricity of components of biodiesel and petrodiesel. The origin of biodiesel lubricity. Energ. Fuel., 19 (3), 1192-1200 (9 pages).

Knothe, G.; Steidley, K. R., (2007). Kinematic viscosity of biodiesel components (fatty acid alkyl esters) and related compounds at low temperatures. Fuel, 86 (16), 2560-2567 (8 pages).

Knothe, G.; van Gerpen, J.; Krahl, J., (2005). Oxidative stability of biodiesel. The Biodiesel Handbook, Chapter 6.4. AOCS Press, Champaign, IL, USA.

Krisnangkura, K.; Yimsuwan, T.; Pairintra, R., (2006). An empirical approach in predicting biodiesel viscosity at various temperatures. Fuel, 85 (1), 107-113 (7 pages).

Lam, M. K.; Tan, K. T.; Lee, K. T.; Mohamed, A. R., (2009). Malaysian palm oil: Surviving the food versus fuel debate for a sustainable future. Renew. Sust. Energ. Rev., 13 (6-7), 1456-1464 (9 pages).

Leadbeater, N. E.; Stencel, L. M., (2006). Fast, easy preparation of biodiesel using microwave heating. Energ. Fuel., 20 (5), 2281-2283 (3 pages).

Lee, I.; Johnson, L. A.; Hammond, E. G., (1995). Use of branched-chain esters to reduce the crystallization temperature of biodiesel. J. Am. Oil Chem. Soc., 72 (10), 1155-1160 (6 pages).

Leung, D. Y. C.; Koo, B. C. P.; Guo, Y., (2006). Degradation of biodiesel under different storage conditions. Bioresour. Tech., 97 (2), 250-256 (7 pages).

Ma, F.; Hanna, M. A., (1999). Biodiesel production: A review. Bioresour. Tech., 70 (1), 1-15 (15 pages).

Mahajan, S.; Konar, S. K.; Boocock, D. G. B., (2006). Determining the acid number of biodiesel. J. Am. Oil Chem. Soc., 83 (6), 567-570 (4 pages).

McCormick, R. L.; Alleman, T. L., (2005). Effect of biodiesel fuel on pollutant emissions from diesel engines. In: Knothe, G.; van Gerpen, J.; Krahl, J. The Biodiesel Handbook, Chapter 7.1. AOCS Press, Champaign, IL, USA.

Meneghetti, S. M. P.; Meneghetti, M. R.; Wolf, C. R.; Silva, E. C.; Lima, G. E. S.; Silva, L. L.; Serra, T. M.; Cauduro, F.; de Oliveira, L. G., (2006a). Biodiesel from castor oil: a comparison of ethanolysis versus methanolysis. Energ. Fuel., 20 (5), 2262-2265 (4 pages)

Meneghetti, S. M. P.; Meneghetti, M. R.; Wolf, C. R.; Silva, E. C.; Lima, G. E. S.; Coimbra, M.; Soletti, J. I.; Carvalho, H. V., (2006b). Ethanolysis of castor and cottonseed oil: A systematic study using classical catalysts. J. Am. Oil Chem. Soc., 83 (9), 819-822 (4 pages).

Monyem, A.; van Gerpen, J. H., (2001). The effect of biodiesel oxidation on engine performance and emissions. Biomass Bioenerg., 20 (4), 317-325 (9 pages).

Naik, M.; Meher, L. C.; Naik, S. N.; Das, L. M., (2008). Production of biodiesel from high free fatty acid Karanja (Pongamia pinnata) oil. Biomass Bioenerg., 32 (4), 354357 (4 pages).

Nascimento, R. S. V.; Soares, V. L. P.; Albinante, S.; Barreto, L. R., (2005). Effect of ester-additives on the crystallization temperature of methyl hexadecanoate. J. Therm. Anal. Calorim., 79 (2), 249-254 (6 pages).

Noor Azian, M.; Mustafa Kamal, A. A.; Panau, F.; Ten, W. K., (2001). Viscosity estimation of triacylglycerols and of Some vegetable oils, based on their triacylglycerol composition. J. Am. Oil Chem. Soc., 78 (10), 1001-1005 (5 pages).

Rabelo, J.; Batista, E.; Cavaleri, F. W.; Meirelles, A. J. A., (2000). Viscosity prediction for fatty systems. J. Am. Oil Chem. Soc., 77 (12), 1255-1262 (8 pages).

Ramadhas, A. S.; Jayaraj, S.; Muraleedharan, C.; Padmakumari, K., (2006). Artificial neural networks used for the prediction of the cetane number of biodiesel. Renew. Energ., 31 (15), 2524-2533 (10 pages).

Refaat, A. A.; Attia, N. K.; Sibak, H. A.; El Sheltawy, S. T.; El Diwani, G. I., (2008a). Production optimization and quality assessment of biodiesel from waste vegetable oil. Int. J. Environ. Sci. Tech., 5 (1), 75-82 (8 pages).

Refaat, A. A.; El Sheltawy, S. T.; Sadek, K. U., (2008b). Optimum reaction time, performance and exhaust emissions of biodiesel produced by microwave irradiation. Int. J. Environ. Sci. Tech., 5 (3), 315-322 (8 pages).

Rodenbush, C. M.; Hsieh, F. H.; Viswanath, D. S., (1999). Density and viscosity of vegetable oils. J. Am. Oil Chem. Soc., 76 (12), 1415-1419 (5 pages).

Rodrigues, J. A.; Cardoso, F. P.; Lachter, E. R.; Estevao, L. R. M.; Lima, E.; Nascimento, R. S. V., (2006). Correlating chemical structure and physical properties of vegetable oil esters. J. Am. Oil Chem. Soc., 83 (4), 353-357 (5 pages).

Sarin, R.; Arora, A. K.; Ranjan, R.; Gupta, A. A.; Malhotra, R. K., (2007). Biodiesel lubricity: Correlation study with residual acidity. Lubr. Sci., 19 (2), 151-157 (7 pages).

Sarin, R.; Kumar, R.; Srivastav, B.; Puri, S. K.; Tuli, D. K.; Malhotra, R. K.; Kumar, A., (2009). Biodiesel surrogates: Achieving performance demands. Bioresour. Tech., 100 (12), 3022-3028 (7 pages).

Scholz, V.; da Silva, J. N., (2008). Prospects and risks of the use of castor oil as a fuel. Biomass Bioenerg., 32 (2), 95 100 (6 pages).

Schumacher, L., (2005). Biodiesel lubricity. In: Knothe, G.; van Gerpen, J.; Krahl, J. The Biodiesel Handbook, Chapter 6.5. AOCS Press, Champaign, IL, USA.

Scott, P. T.; Pregelj, L.; Chen, N.; Hadler, J. S.; Djordjevic, M. A.; Gresshoff, P. M., (2008). Pongamia pinnata: An untapped resource for the biofuels industry of the future. Bioenerg. Res., 1 (1), 2-11 (10 pages).

Scrimgeour, C., (2005). Chemistry of fatty acids. In: Bailey's industrial oil and fat products, 6 (Ed.) Six Volume Set, Vol. 1: Edible oil and fat products, Chapter 1. John Wiley and Sons, Inc., New York.

Singh, A.; He, B.; Thompson, J.; Van Gerpen, J., (2006). Process optimization of biodiesel production using different alkaline catalysts. Applied Engineering in Agriculture, 22 (4), 597600 (4 pages). 
Srinivasan, S., (2009). The food $\mathrm{v}$ fuel debate: A nuanced view of incentive structures. Renew. Energ., 34 (4), 950954 (5 pages).

Srivastava, A.; Prasad, R., (2001). Rheological behaviour of fatty acid methyl esters. Indian J. Chem. Tech., 8 (6), 473481 (9 pages).

Sujatha, M.; Reddy, T. P.; Mahasi, M. J., (2008). Role of biotechnological interventions in the improvement of castor (Ricinus communis L.) and Jatropha curcas L. Biotech. Adv., 26 (5), 424-435 (12 pages).

Tang, H.; Wang, A.; Salley, S. O.; Simon, K. Y., (2008). The effect of natural and synthetic antioxidants on the oxidative stability of biodiesel. J. Am. Oil Chem. Soc., 85 (4), 373382 (10 pages).

Tangsathitkulchai, C.; Sittichaitaweekul, Y.; Tangsathitkulchai, M., (2004). Temperature effect on the viscosities of palm oil and coconut oil blended with diesel oil. J. Am. Oil Chem. Soc., 81 (4), 401-405 (5 pages).

Tat, M. E.; van Gerpen, J. H., (1999). The kinematic viscosity of biodiesel and its blends with diesel fuel. J. Am. Oil Chem. Soc., 76 (12), 1511-1513 (3 pages).

Tat, M. E.; van Gerpen, J. H., (2000). The specific gravity of biodiesel and its blends with diesel fuel. J. Am. Oil Chem. Soc., 77 (2), 115-119 (5 pages).

Tat, M. E.; van Gerpen, J. H.; Wang, P. S.; Clemente, T. E., (2007). Exhaust emissions from an engine fueled with biodiesel from high-oleic soybeans. J. Am. Oil Chem. Soc., 84 (9), 865-869 (5 pages).

Tate, R. E.; Watts, K. C.; Allen, C. A. W.; Wilkie, K. I., (2006). The viscosities of three biodiesel fuels at temperatures up to $300{ }^{\circ} \mathrm{C}$. Fuel, 85 (7-8), 1010-1015 (6 pages).

Thompson, J. C., Peterson, C. L.; Reece, D. L.; Beck, S. M.; (1998). Two-year storage study with methyl and ethyl esters of rapeseed. Am. Soc. Agric. Eng., 41 (4), 931-939 (9 pages).

van Gerpen, J. H., (1996). Cetane number testing of biodiesel. Proceedings of the $3^{\text {rd }}$ Liquid Fuel Conference: Liquid Fuel and Industrial Products from Renewable Resources, American
Society of Agricultural Engineers (ASAE), September 1517, 1996, Nashville, TN, USA, 197-206.

van Gerpen, J. H.; Knothe, G., (2005). Basics of the Transesterification Reaction. In: Knothe, G.; van Gerpen, J.; Krahl, J. The Biodiesel Handbook, Chapter 4.1. AOCS Press, Champaign, IL, USA.

van Gerpen, J. H.; Peterson, C. L.; Goering, C. E., (2007). Biodiesel: An alternative fuel for compression ignition engines. Proceedings of the Agricultural Equipment Technology Conference, Louisville, Kentucky, USA, 11-14 February 2007, ASAE Publication No. 913C0107.

van Gerpen, J. H.; Seref, S.; Tat, M. E., (1999). Evaluation of the lubricity of soybean oil-based additives in diesel fuel. American Society of Agricultural Engineers, ASAE Annual International Meeting, Torontoo, Ontario, Canada, July 18July 21, 1999, Paper No.: 966134.

Vicente, G; Martinez, M.; Aracil, J., (2005). Optimization of brassica carinata oil methanolysis for biodiesel production. J. Am. Oil Chem. Soc., 82 (12), 899-904 (6 pages).

Wain, K. S.; Perez, J. M., (2002). Oxidation of biodiesel fuel for improved lubricity. ASME 2002-ICE-447, ICE, 38, 2734 (8 pages).

Wang, T.; Briggs, J. L., (2002). Rheological and thermal properties of soybean oils with modified fatty acid compositions. J. Am. Oil Chem. Soc., 79 (8), 831-836 (6 pages).

WCO, (2007). The harmonized commodity description and coding system (HS). World Customs Organization, Brussels, Belgium.

Yanishlieva, N. V.; Kamal-Eldin, A.; Marinova, E. M.; Toneva, A. G., (2002). Kinetics of antioxidant action of $\alpha$ - and $\gamma-$ toco-pherols in sunflower and soybean triacylglycerols. Eur. J. Lipid Sci. Tech., 104 (5), 262-270 (9 pages).

Yuan, W.; Hansen, A. C.; Zhang, Q.; Tan, Z., (2005). Temperature-dependent kinematic viscosity of selected biodiesel fuels and blends with diesel fuel. J. Am. Oil Chem. Soc., 82 (3), 195-199 (5 pages).

\section{AUTHOR (S) BIOSKETCHES}

Refaat, A. A., B.Sc. (Hons), M.Sc., is a teaching assistant in the Department of Chemical Engineering, Faculty of Engineering, Cairo University, Egypt. Email: aarefaat@hotmail.com

How to cite this article: (Harvard style)

Refaat, A. A., (2009). Correlation between the chemical structure of biodiesel and its physical properties. Int. J. Environ. Sci. Tech., 6 (4), 677-694. 